\title{
SCIENTIFIC REPORTS

\section{Influence of Pichia pastoris X-33 produced in industrial residues on productive performance, egg quality, immunity, and intestinal morphometry in quails}

\author{
Giana Carla Gaboardi ${ }^{1 *}$, Débora Alves ${ }^{2}$, Diego Gil de los Santos ${ }^{3}$, Eduardo Xavier ${ }^{2}$, \\ Ana Paula Nunes ${ }^{4}$, Paula Finger ${ }^{1}$, Emili Griep ${ }^{1}$, Victor Roll ${ }^{2}$, Patrícia Oliveira ${ }^{1}$, Arthur Silva ${ }^{1}$, \\ Ângela Moreira ${ }^{5}$ \& Fabricio Conceição ${ }^{1}$
}

This study was conducted in quails to evaluate the probiotic potential of Pichia pastoris X-33, cultivated in parboiled rice effluent supplemented with biodiesel glycerol or in standard medium Yeast ExtractPeptone-Dextrose (YPD). Forty-days-old female quails were divided into three treatments: T1 (Control) received a basal diet without $P$. pastoris; T2 (Pichia Effluent) received a basal diet supplemented with $P$. pastoris grown in parboiled rice effluent and biodiesel glycerol, and T3 (Pichia YPD) received a basal diet supplemented with $P$. pastoris produced in YPD. The birds were vaccinated against Newcastle Disease (NDV), Avian Infectious Bronchitis (IBV), and Gumboro Disease on days 1 and 28. The following parameters were analyzed: performance, egg quality, humoral immune response to the vaccines, organ weight, and intestinal morphometry. $P$. pastoris grown in YPD increased egg weight $(\mathrm{p}<0.05)$. The lowest liver weight on day 14 was obtained in Pichia Effluent, whereas both P. pastoris supplemented groups had the lowest duodenum weights on day 14. Besides that, livers and duodenums presented no morphological changes in any of the three treatments. Supplementation of $P$. pastoris modulated the immune system of the birds, increasing anti-IBV, anti-NDV, and anti-Gumboro antibodies levels compared to the Control ( $\mathrm{p}<0.05$ ). In conclusion, quail's immune response was improved by Pichia pastoris X-33, either it was grown in YPD or industrial residues, and the egg weight increased with Pichia pastoris X-33 grown in YPD, thereby demonstrating to be a promising probiotic for poultry.

For decades, it was a common practice to use antibiotics as growth promoters in animal production to increase food efficiency, promote growth, and improve the quality of products ${ }^{1}$. However, its indiscriminate use raised fear about the development of resistance mechanisms to antibiotics and the transfer of resistant bacteria from animals to humans, and for this reason, its use as growth promoters was first banned by the European Community ${ }^{2,3}$ and later by several other countries. Since then, a number of alternatives have been proposed and tested ${ }^{4}$ in a search for an ideal substitute that exerts the same effects: increased performance and immunomodulatory activity ${ }^{5,6}$.

In this sense, interest in probiotics for animal use has intensified, encouraging the exploration of new probiotic species as safe and low-cost alternatives to antibiotics ${ }^{7,8}$. Probiotics are living microorganisms that, when ingested in adequate doses, confer benefits to the host ${ }^{9}$. Animal diet supplementation with probiotics has positively modulated the immune response, decreased infection by enteropathogenic bacteria, increased food efficiency ${ }^{10-12}$, and improved egg quality in chickens ${ }^{13-15}$

Pichia pastoris is a methylotrophic yeast that has been used as a recombinant protein expression system for over two decades; it is especially useful in the production of complex proteins that require post-translational

\footnotetext{
${ }^{1}$ Centro de Desenvolvimento Tecnológico, Universidade Federal de Pelotas, Pelotas, Brazil. ${ }^{2}$ Faculdade de Agronomia, Universidade Federal de Pelotas, Pelotas, Brazil. ${ }^{3}$ Instituto Federal Sul-rio-grandense, Campus Pelotas, Pelotas, Brazil. ${ }^{4}$ Faculdade de Medicina, Universidade Federal de Pelotas, Pelotas, Brazil. ${ }^{5}$ Faculdade de Nutrição, Universidade Federal de Pelotas, Pelotas, Brazil. *email: giana_gaboardi@hotmail.com
} 
modifications to fold and function correctly ${ }^{16-18}$. Some of special features of $P$. pastoris include high cell density production in simple and low-cost media and its GRAS (Generally Recognized as Safe) status, which ensures the safety of its application in therapeutic strategies and production of single-cell proteins ${ }^{19}$. Recently, explorations of its potential as a probiotic have revealed that $P$. pastoris exerts antimicrobial activity against Salmonella Typhimurium in mice ${ }^{20}$ and increases weight gain, improves feed conversion, and modulates the humoral immune response in broilers ${ }^{21,22}$. As a strategy to decrease the costs of probiotic production, studies has been conducted in this regard, showing the efficient growth of $P$. pastoris $\mathrm{X}-33$ in agroindustrial waste. In this sense, $P$. pastoris can grow in parboiled rice effluent supplemented with glycerol byproduct of biodiesel, with large biomass production, high cellular viability, reduction of chemical oxygen demand (COD), and removal of nitrogen and phosphorus to levels required by environmental inspection agencies ${ }^{23}$, making it possible to treat the effluent and add value as a culture medium. These results suggest that $P$. pastoris may be produced at a low cost for beneficial applications as a probiotic in poultry.

Quail farming is a sector of poultry currently expanding in Brazil, where it is designed for the production of meat and eggs. In the last decades, quail farming was no longer considered a subsistence practice and began to occupy a position of highly-qualified activity with promising results for investors ${ }^{24,25}$. Among the attractive characteristics of quails are fast growth, early sexual maturity, early posture, short incubation period, high productivity, persistence in egg production, housing of large populations in small spaces and low cost of housing ${ }^{25-27}$. Some previous studies in quails have already indicated the beneficial effects of probiotic administration on performance, egg quality, blood biochemical parameters, intestinal morphology, immunomodulation, and protection against toxins ${ }^{28-30}$.

Considering the reported benefits of Pichia pastoris as a probiotic and the lack of data about its effect in quails, this study was conducted to evaluate how Pichia pastoris X-33, cultivated in either standard culture medium or industrial effluent, affects quail performance, egg quality, intestinal morphology, and immune response modulation.

\section{Results}

Pichia pastoris X-33 cell viability and stability. In both Yeast Extract-Peptone-Dextrose (YPD) and alternative medium (effluent supplemented with biodiesel glycerol), $10^{8} \mathrm{CFU} \cdot \mathrm{mL}^{-1}$ was obtained. P. pastoris cell pellets were kept refrigerated at $4^{\circ} \mathrm{C}$, resuspended in $0.9 \%$ saline solution throughout the experiment (84 days). During this period, cell viability decreased in the last month only, by $0.5 \log . \mathrm{mL}^{-1}$. In the diets, yeast viability was maintained without a decrease in the concentration of viable cells, probably because fresh yeast was mixed into the diet every week.

Performance. The performance variables analyzed during the experiment are shown in Table 1. The initial body weight of the birds was statistically equivalent in all groups $(\mathrm{p}>0.05)$. The body weight was statistically higher in Pichia Effluent group in relation to Pichia YPD group on day 84, with a difference of $26 \mathrm{~g}$. Numerically, Pichia Effluent group had the highest weight values after day 28. These results also reflected in the weight gain, which showed the same pattern, with a significant difference between the Pichia Effluent and Pichia YPD groups. Feed intake was maintained throughout the experimental period at approximately $42 \mathrm{~g} / \mathrm{bird} / \mathrm{day}$. No group differed significantly in egg production (\%), although egg production increased numerically during the analyzed period in the Pichia groups. On day 28, the control group obtained the worst feed conversion, compared to both of the groups supplemented with $P$. pastoris. After day 28, this parameter improved numerically but non-significantly in all the groups.

Egg quality. Internal egg quality variables are described in Table 2. The average egg weight in the Pichia YPD group was significantly higher than in control group $(\mathrm{p}<0.05)$, with an increase of $1 \mathrm{~g}$ in egg weight between days 28 and 56, and an increase of $1.7 \mathrm{~g}$ between days 56 and 84, in the Pichia YPD group compared to the control group. On day 28, the highest yolk percentages were obtained in the control and Pichia YPD groups, which did not differ from each other, but both were significantly higher than the Pichia Effluent group $(\mathrm{p}<0.05)$. After day 28 , there was no significant variation in the yolk percentages between the groups. The other internal egg quality variables (yolk weight, albumen percentage, albumen weight) and yolk color showed no variation or difference between groups at any point during the experiment, except for the difference in the parameter a* (redness) in Pichia YPD and control groups on day 84 (Table 3). No significant difference was found in the Haugh Unit scores, but a gradual increase occurred in all treatments from day 28 onwards.

The external egg quality measurements can be observed in Table 4 . There was no significant difference in specific gravity between the treatments; however, the Pichia Effluent and Pichia YPD groups maintained the values throughout the experiment, while the control treatment had a progressive decrease in the specific gravity throughout the experiment. The eggshell weight was equal between treatments on all the days analyzed, with increase of $0.04 \mathrm{~g}$ in the final eggshell weights, in relation to initial weight in all treatments. On day 56, the highest eggshell percentage was observed in the Pichia YPD treatment, but it was not statistically different from the Pichia Effluent treatment and control group $(\mathrm{p}>0.05)$. The eggshell thickness remained unchanged, without variations between the periods analyzed and between treatments.

Humoral immune response. Blood samples from days 14, 28, 56, and 84 were collected and tested by indirect ELISA, using as antigens the monovalent vaccines against Gumboro Disease, Infectious Bronchitis, and Newcastle Disease. The best antibody response was observed against Gumboro Disease (Fig. 1A), with higher absorbances at 56 and 84 days post-vaccination in both the Pichia Effluent and Pichia YPD groups compared to the control $(\mathrm{p}<0.05)$. On day 84 , the levels of anti-Gumboro antibodies in P. pastoris supplemented groups were approximately twice higher than in the control group. On day 28, the Pichia Effluent group had higher levels 


\begin{tabular}{|c|c|c|c|c|c|c|c|c|}
\hline & \multirow[b]{2}{*}{ Time } & \multicolumn{3}{|c|}{ Treatments } & \multirow[b]{2}{*}{ SEM } & \multicolumn{3}{|l|}{$P$-value } \\
\hline & & Control & Pichia Effluent & Pichia YPD & & Treatment & Time & Treat*Time \\
\hline \multirow{4}{*}{ Body weight (g) } & $0 \mathrm{~d}$ & 305.30 & 301.27 & 305.26 & \multirow{4}{*}{2.600} & \multirow{4}{*}{0.0322} & \multirow{4}{*}{$<0.0001$} & \multirow{4}{*}{0.9571} \\
\hline & $0-28 \mathrm{~d}$ & 363.91 & 370.05 & 359.20 & & & & \\
\hline & $28-56 \mathrm{~d}$ & 389.06 & 397.58 & 384.99 & & & & \\
\hline & $56-84 \mathrm{~d}$ & $404.93^{\mathrm{ab}}$ & $415.98^{\mathrm{a}}$ & $389.65^{\mathrm{b}}$ & & & & \\
\hline \multirow{3}{*}{ Body weight gain (g) } & $0-28 \mathrm{~d}$ & 58.61 & 68.78 & 53.94 & & \multirow{3}{*}{0.0110} & \multirow{3}{*}{$<0.0001$} & \multirow{3}{*}{0.9799} \\
\hline & $28-56 \mathrm{~d}$ & 83.77 & 96.31 & 79.74 & 2.501 & & & \\
\hline & $56-84 \mathrm{~d}$ & $99.63^{\mathrm{ab}}$ & $114.70^{\mathrm{a}}$ & $84.40^{\mathrm{b}}$ & & & & \\
\hline \multirow{4}{*}{ Feed intake (g/d) } & $0-28 \mathrm{~d}$ & 42.52 & 42.51 & 41.59 & \multirow{4}{*}{0.334} & \multirow{4}{*}{0.5488} & \multirow{4}{*}{0.8701} & \multirow{4}{*}{0.8730} \\
\hline & $28-56 \mathrm{~d}$ & 42.66 & 42.53 & 41.89 & & & & \\
\hline & $56-84 \mathrm{~d}$ & 41.89 & 43.43 & 42.47 & & & & \\
\hline & Average & 42.35 & 42.82 & 41.98 & & & & \\
\hline \multirow{4}{*}{ Egg production (\%) } & $0-28 \mathrm{~d}$ & 78.53 & 79.23 & 85.28 & \multirow{4}{*}{1.242} & \multirow{4}{*}{0.9047} & \multirow{4}{*}{0.0010} & \multirow{4}{*}{0.2772} \\
\hline & $28-56 \mathrm{~d}$ & 93.23 & 86.48 & 85.37 & & & & \\
\hline & $56-84 \mathrm{~d}$ & 91.21 & 93.54 & 91.44 & & & & \\
\hline & Average & 87.66 & 86.42 & 87.36 & & & & \\
\hline \multirow{4}{*}{ Egg mass (g/bird/d) } & $0-28 \mathrm{~d}$ & 11.30 & 11.22 & 11.68 & \multirow{4}{*}{0.432} & \multirow{4}{*}{0.5881} & \multirow{4}{*}{0.2711} & \multirow{4}{*}{0.794} \\
\hline & $28-56 \mathrm{~d}$ & 13.98 & 12.70 & 12.25 & & & & \\
\hline & $56-84 \mathrm{~d}$ & 13.87 & 13.64 & 13.33 & & & & \\
\hline & Average & 13.05 & 12.52 & 12.42 & & & & \\
\hline \multirow{4}{*}{ Feed conversion/Egg mass $(\mathrm{g} / \mathrm{g})$} & $0-28 \mathrm{~d}$ & 5.19 & 4.30 & 3.81 & \multirow{4}{*}{0.153} & \multirow{4}{*}{0.7984} & \multirow{4}{*}{0.0019} & \\
\hline & $28-56 \mathrm{~d}$ & 3.11 & 3.75 & 3.62 & & & & 02127 \\
\hline & $56-84 \mathrm{~d}$ & 3.07 & 3.18 & 3.25 & & & & 0.2127 \\
\hline & Average & 3.79 & 3.74 & 3.56 & & & & \\
\hline
\end{tabular}

Table 1. Productive performance of quails fed diets containing Pichia pastoris X-33 grown in parboiled rice effluent supplemented with biodiesel glycerol or in YPD medium. Different superscript letters in the same row indicate significant difference between averages $(P<0.05)$ by Tukey's test; SEM $=$ Standard error of the mean. Control $=$ basal diet; Pichia Effluent $=$ basal diet + P. pastoris X-33 grown in parboiled rice effluent supplemented with biodiesel glycerol; Pichia $\mathrm{YPD}=$ basal diet + P. pastoris X-33 grown in YPD medium.

of anti-Gumboro antibodies than the other groups. The production of anti-Newcastle antibodies was greater in the Pichia YPD group than in the control group on day 84 (Fig. 1C), whereas in the same period, the Pichia Effluent group had a higher response against the Infectious Bronchitis virus (Fig. 1B) compared to the control group $(\mathrm{p}=0.0657)$. The anti-NDV antibodies titers obtained by the hemagglutination inhibition (HI) test were also higher on day 84 in the Pichia YPD group compared to the control group $(\mathrm{p}<0.05)$, with a 1.8 -fold increase in the title (Table 5). The control group had the lowest titer of anti-NDV antibodies in this period. There was no difference in anti-NDV antibodies titers between the Pichia Effluent and Pichia YPD groups in any of the analyzed periods.

Relative organ weights. Table 6 shows the relative weight of internal organs ( $\mathrm{g} / 100 \mathrm{~g}$ body weight) of quails of the Pichia Effluent, Pichia YPD, and control groups. The treatments had no effect on the relative weight of the heart, which was maintained throughout the experiment. In addition, there was no significant difference between treatments for the relative weight of lymphoid organs (spleen, bursa of Fabricius, and cecal tonsils) in any of the analyzed periods. The relative weight of the liver was lower in the Pichia Effluent group compared to the control group on day $14(\mathrm{p}<0.05)$. Supplementation with $P$. pastoris, produced in both culture media tested, significantly reduced the weight of the duodenum on days 14 and 84 when compared to the control group.

Intestinal morphometry and safety. The results of intestinal morphometry are shown in Table 7. Supplementation with $P$. pastoris X-33 grown in standard or alternative medium did not interfere significantly in the villi height nor crypt depth $(\mathrm{p}>0.05)$. An increase in average values of villi height and crypt depth was observed in all groups throughout the experiment. The analysis of the liver and duodenum samples did not reveal any lesions in any of the groups tested.

\section{Discussion}

One of the requirements for a microorganism to be used as probiotic is the ability to preserve its viability for long periods of storage. In this study, $P$. pastoris remained viable for approximately three months without a significant decrease in concentration or impairment of viability. This finding concurs with França et al. ${ }^{20}$, which had already reported at least two months viability of $P$. pastoris in the diet of mice.

$P$. pastoris X-33 cultivated in parboiling rice effluent supplemented with biodiesel glycerol was tested for its probiotic properties in mixed-breed quails and was found to confer a positive effect mainly on the immunity of the animals. Additionally, P. pastoris did not cause harmful effects on performance nor egg quality. The use 


\begin{tabular}{|c|c|c|c|c|c|c|c|c|}
\hline & \multirow[b]{2}{*}{ Time } & \multicolumn{3}{|c|}{ Treatments } & \multirow[b]{2}{*}{ SEM } & \multicolumn{3}{|l|}{$P$-value } \\
\hline & & Control & Pichia Effluent & Pichia YPD & & Treatment & Time & Treat*Time \\
\hline \multirow{4}{*}{ Egg weight (g) } & $0-28 \mathrm{~d}$ & 14.24 & 14.52 & 14.20 & \multirow{4}{*}{0.108} & \multirow{4}{*}{0.0254} & \multirow{4}{*}{0.0664} & \multirow{4}{*}{0.8204} \\
\hline & $28-56 \mathrm{~d}$ & $14.37^{\mathrm{b}}$ & $15.11^{\mathrm{ab}}$ & $15.35^{\mathrm{a}}$ & & & & \\
\hline & $56-84 \mathrm{~d}$ & $14.24^{\mathrm{b}}$ & $15.25^{\mathrm{ab}}$ & $15.95^{\mathrm{a}}$ & & & & \\
\hline & Average & 14.04 & 14.96 & 15.16 & & & & \\
\hline \multirow{4}{*}{ Yolk weight (g) } & $0-28 \mathrm{~d}$ & 4.24 & 4.13 & 4.29 & \multirow{4}{*}{0.037} & \multirow{4}{*}{0.9417} & \multirow{4}{*}{0.0005} & \multirow{4}{*}{0.6902} \\
\hline & $28-56 \mathrm{~d}$ & 4.57 & 4.50 & 4.38 & & & & \\
\hline & $56-84 \mathrm{~d}$ & 4.51 & 4.57 & 4.62 & & & & \\
\hline & Average & 4.44 & 4.40 & 4.43 & & & & \\
\hline \multirow{4}{*}{ Yolk ratio (\%) } & $0-28 \mathrm{~d}$ & $29.02^{\mathrm{a}}$ & $26.88^{\mathrm{b}}$ & $30.20^{\mathrm{a}}$ & \multirow{4}{*}{0.247} & \multirow{4}{*}{0.0137} & \multirow{4}{*}{0.0237} & \multirow{4}{*}{0.1942} \\
\hline & $28-56 \mathrm{~d}$ & 29.38 & 29.78 & 30.62 & & & & \\
\hline & $56-84 \mathrm{~d}$ & 29.94 & 29.98 & 30.87 & & & & \\
\hline & Average & 29.45 & 28.88 & 30.57 & & & & \\
\hline \multirow{4}{*}{ Albumen weight (g) } & $0-28 \mathrm{~d}$ & 7.61 & 7.59 & 7.27 & \multirow{4}{*}{0.069} & \multirow{4}{*}{0.1248} & \multirow{4}{*}{0.1012} & \multirow{4}{*}{0.9664} \\
\hline & $28-56 \mathrm{~d}$ & 7.78 & 8.03 & 7.61 & & & & \\
\hline & $56-84 \mathrm{~d}$ & 7.78 & 7.98 & 7.66 & & & & \\
\hline & Average & 7.72 & 7.86 & 7.51 & & & & \\
\hline \multirow{4}{*}{ Albumen ratio (\%) } & $0-28 \mathrm{~d}$ & 51.85 & 49.49 & 51.26 & \multirow{4}{*}{0.466} & \multirow{4}{*}{0.4968} & \multirow{4}{*}{0.2143} & \multirow{4}{*}{0.2740} \\
\hline & $28-56 \mathrm{~d}$ & 51.44 & 53.08 & 52.98 & & & & \\
\hline & $56-84 \mathrm{~d}$ & 48.50 & 52.33 & 51.19 & & & & \\
\hline & Average & 50.59 & 51.63 & 51.81 & & & & \\
\hline \multirow{4}{*}{ Haugh Unit } & $0-28 \mathrm{~d}$ & 92.26 & 92.00 & 92.71 & \multirow{4}{*}{0.365} & \multirow{4}{*}{0.8224} & & \\
\hline & $28-56 \mathrm{~d}$ & 92.50 & 92.29 & 92.41 & & & 00532 & 06890 \\
\hline & $56-84 \mathrm{~d}$ & 94.01 & 95.69 & 93.22 & & & 0.0532 & 0.6890 \\
\hline & Average & 92.92 & 93.33 & 92.78 & & & & \\
\hline
\end{tabular}

Table 2. Internal egg quality parameters of quails fed diets containing Pichia pastoris X-33 grown in parboiled rice effluent supplemented with biodiesel glycerol or in YPD medium. Different superscript letters in the same row indicate significant difference between averages $(P<0.05)$ by Tukey's test; $S E M=$ Standard error of the mean. Control = basal diet; Pichia Effluent $=$ basal diet $+P$. pastoris X-33 grown in parboiled rice effluent supplemented with biodiesel glycerol; Pichia $\mathrm{YPD}=$ basal diet + P. pastoris X-33 grown in YPD medium.

\begin{tabular}{|c|c|c|c|c|c|c|c|c|}
\hline & \multirow[b]{2}{*}{ Time } & \multicolumn{3}{|c|}{ Treatments } & \multirow[b]{2}{*}{ SEM } & \multicolumn{3}{|l|}{$P$-value } \\
\hline & & Control & Pichia Effluent & Pichia YPD & & Treatment & Time & Treat*Time \\
\hline \multirow{4}{*}{$\begin{array}{l}\text { Yolk color }\left(\mathrm{DSM}^{\circledR}\right. \\
\text { color fan) }\end{array}$} & $0-28 \mathrm{~d}$ & 3.80 & 3.91 & 4.10 & \multirow{4}{*}{0.037} & \multirow{4}{*}{0.7723} & \multirow{4}{*}{$<0.0001$} & \multirow{4}{*}{0.1197} \\
\hline & $28-56 \mathrm{~d}$ & 4.16 & 4.31 & 4.23 & & & & \\
\hline & $56-84 \mathrm{~d}$ & 3.91 & 3.73 & 3.71 & & & & \\
\hline & Average & 3.95 & 3.98 & 4.01 & & & & \\
\hline \multirow{4}{*}{ Lightness $\left(\mathrm{L}^{*}\right)$} & $0-28 \mathrm{~d}$ & 56.81 & 58.82 & 57.15 & \multirow{4}{*}{0.297} & \multirow{4}{*}{0.3562} & \multirow{4}{*}{0.0001} & \multirow{4}{*}{0.4229} \\
\hline & $28-56 \mathrm{~d}$ & 59.62 & 59.86 & 59.44 & & & & \\
\hline & $56-84 \mathrm{~d}$ & 56.18 & 57.89 & 58.05 & & & & \\
\hline & Average & 57.54 & 58.86 & 58.21 & & & & \\
\hline \multirow{4}{*}{ Redness $\left(\mathrm{a}^{*}\right)$} & $0-28 \mathrm{~d}$ & -5.47 & -5.58 & -5.44 & \multirow{4}{*}{0.059} & \multirow{4}{*}{0.0366} & \multirow{4}{*}{$<0.0001$} & \multirow{4}{*}{0.1539} \\
\hline & $28-56 \mathrm{~d}$ & -4.92 & -4.76 & -5.00 & & & & \\
\hline & $56-84 \mathrm{~d}$ & $-5.68^{b}$ & $-5.98^{\mathrm{ab}}$ & $-6.21^{\mathrm{a}}$ & & & & \\
\hline & Average & -5.36 & -5.44 & -5.55 & & & & \\
\hline \multirow{4}{*}{ Yellowness (b*) } & $0-28 \mathrm{~d}$ & 35.51 & 36.37 & 35.18 & \multirow{4}{*}{0.308} & \multirow{4}{*}{0.1573} & \multirow{4}{*}{$<0.0001$} & \multirow{4}{*}{0.9582} \\
\hline & $28-56 \mathrm{~d}$ & 39.68 & 40.57 & 38.59 & & & & \\
\hline & $56-84 \mathrm{~d}$ & 36.35 & 37.00 & 36.26 & & & & \\
\hline & Average & 37.18 & 37.98 & 36.68 & & & & \\
\hline
\end{tabular}

Table 3. Egg yolk color parameters of quails fed diets containing Pichia pastoris X-33 grown in parboiled rice effluent supplemented with biodiesel glycerol or in YPD medium. Different superscript letters in the same row indicate significant difference between averages $(P<0.05)$ by Tukey's test; SEM $=$ Standard error of the mean. Control = basal diet; Pichia Effluent $=$ basal diet + P. pastoris $\mathrm{X}-33$ grown in parboiled rice effluent supplemented with biodiesel glycerol; Pichia $\mathrm{YPD}=$ basal diet + P. pastoris X-33 grown in YPD medium. 


\begin{tabular}{|c|c|c|c|c|c|c|c|c|}
\hline & \multirow[b]{2}{*}{ Time } & \multicolumn{3}{|c|}{ Treatments } & \multirow[b]{2}{*}{ SEM } & \multicolumn{3}{|l|}{$P$-value } \\
\hline & & Control & Pichia Effluent & Pichia YPD & & Treatment & Time & Treat*Time \\
\hline \multirow{4}{*}{ Specific gravity } & $0-28 \mathrm{~d}$ & 1074.80 & 1075.13 & 1074.80 & \multirow{4}{*}{3.729} & \multirow{4}{*}{0.4097} & \multirow{4}{*}{0.6756} & \multirow{4}{*}{0.5044} \\
\hline & $28-56 \mathrm{~d}$ & 1069.50 & 1069.13 & 1070.80 & & & & \\
\hline & $56-84 \mathrm{~d}$ & 1046.00 & 1077.69 & 1076.50 & & & & \\
\hline & Average & 1063.43 & 1073.98 & 1074.03 & & & & \\
\hline \multirow{4}{*}{ Eggshell weight (g) } & $0-28 \mathrm{~d}$ & 1.15 & 1.14 & 1.13 & \multirow{4}{*}{0.010} & \multirow{4}{*}{0.5096} & \multirow{4}{*}{0.1717} & \multirow{4}{*}{0.9905} \\
\hline & $28-56 \mathrm{~d}$ & 1.16 & 1.12 & 1.13 & & & & \\
\hline & $56-84 \mathrm{~d}$ & 1.19 & 1.18 & 1.16 & & & & \\
\hline & Average & 1.17 & 1.15 & 1.14 & & & & \\
\hline \multirow{4}{*}{ Eggshell ratio (\%) } & $0-28 \mathrm{~d}$ & 7.88 & 7.85 & 7.92 & \multirow{4}{*}{0.048} & \multirow{4}{*}{0.3178} & \multirow{4}{*}{0.0567} & \multirow{4}{*}{0.5900} \\
\hline & $28-56 \mathrm{~d}$ & 7.56 & 7.41 & 7.86 & & & & \\
\hline & $56-84 \mathrm{~d}$ & 7.83 & 7.74 & 7.77 & & & & \\
\hline & Average & 7.75 & 7.67 & 7.85 & & & & \\
\hline \multirow{4}{*}{ Eggshell thickness (mm) } & $0-28 \mathrm{~d}$ & 0.290 & 0.287 & 0.291 & \multirow{4}{*}{0.002} & \multirow{4}{*}{0.7663} & \multirow{4}{*}{0.0511} & \multirow{4}{*}{0.9042} \\
\hline & $28-56 \mathrm{~d}$ & 0.298 & 0.298 & 0.307 & & & & \\
\hline & $56-84 \mathrm{~d}$ & 0.299 & 0.297 & 0.296 & & & & \\
\hline & Average & 0.296 & 0.294 & 0.298 & & & & \\
\hline
\end{tabular}

Table 4. External egg quality parameters of quails fed diets containing Pichia pastoris X-33 grown in parboiled rice effluent supplemented with biodiesel glycerol or in YPD medium. Different superscript letters in the same row indicate significant difference between averages $(P<0.05)$ by Tukey's test; SEM = Standard error of the mean. Control = basal diet; Pichia Effluent $=$ basal diet + P. pastoris X-33 grown in parboiled rice effluent supplemented with biodiesel glycerol; Pichia YPD = basal diet + P. pastoris X-33 grown in YPD medium.

of probiotics has already been evaluated in other types of animal production and beneficial effects have been demonstrated in pigs ${ }^{12,31,32}$, ruminants ${ }^{33-37}$, and poultry. In poultry farming, the main probiotics effects observed are the improvement on broiler performance and antimicrobial activity against intestinal pathogens such as Salmonella spp., Campylobacter spp., Escherichia coli, and Clostridium perfringens ${ }^{38-43}$. In quails, the administration of a single probiotic species or a probiotic consortium has been demonstrated to promote weight gain, improve blood biochemical parameters such as decrease on triglycerides and cholesterol levels ${ }^{30}$, protect against aflatoxins present in the diet, and modulate the immune system ${ }^{28,29}$.

Supplementation of the diet of quails with P. pastoris did not exert significant effects on the productive parameters (weight, weight gain, and feed conversion) compared to the control group, although numerically, the highest values of weight and weight gain were found in the Pichia Effluent group. Seifi and collaborators ${ }^{30}$ tested a commercial probiotic in one-day-old quails and concluded that early administration of probiotics was an essential factor to be possible to observe the probiotic's positive effects in the animals. This may be because newborn chicks do not have yet a fully-formed microbiota and may be contaminated with pathogenic species from the non-sterile environment of incubators. Thus, the inclusion of probiotics in early life may protect against opportunistic pathogens by colonizing the gastrointestinal tract with beneficial species and thereby, preventing the attachment of intestinal pathogens ${ }^{42}$. In this study, $P$. pastoris was first administered when the quails were already 40 days old, which may have inhibited the observation of more pronounced effects of yeast activity.

Additionally, the potentiation of probiotic effect seems to be linked to two factors: inappropriate housing conditions and the presence of health challenges ${ }^{44}$. The work of Jin et al.$^{45}$ supports this theory, observing that broilers subjected to an average temperature of $30^{\circ} \mathrm{C}$ and $95 \%$ relative humidity showed improvement in feed efficiency when fed with a diet supplemented with Lactobacillus acidophilus or with a mixture of 12 Lactobacillus strains. Besides that, studies have reported a positive influence of probiotics on the performance and intestinal morphology of chickens that were challenged with different intestinal pathogens ${ }^{46-48}$. Throughout the present experiment, the animals were kept under conditions of thermal comfort in a properly sanitized room, with water ad libitum, and they were not subjected to any type of stress or challenge with pathogenic species, which may have masked the beneficial effects of $P$. pastoris.

Quails that were fed with a basal diet containing P. pastoris X-33 grown in YPD had an increase on egg weight by $7 \%(1.0 \mathrm{~g})$ at 56 days and $12 \%(1.7 \mathrm{~g})$ at 84 days, compared to the control $(\mathrm{p}<0.05)$. These results are similar to those obtained in laying hens with the dietary supplementation of Bacillus subtilis ${ }^{49}$ and Pediococcus acidilactici ${ }^{50}$, and higher than those observed in chickens receiving Bacillus licheniformis ${ }^{51}$. The possibility of increment in the egg weight is desirable from an economic viewpoint since it enhances the acceptability by the consumer.

Eggshell quality was not influenced by yeast supplementation. Although no statistical difference had been obtained between the groups in the specific gravity, an indicator of eggshell quality, the control group showed a decrease in this parameter in the end of the experiment, while the groups receiving P. pastoris maintained the values throughout the period. The action of probiotics in the intestinal tract creates a more favorable environment by decreasing luminal $\mathrm{pH}$, increasing the solubility of nutrients such as calcium, nitrogen, and phosphorus and thus, improves their absorption ${ }^{49,50,52,53}$. The inclusion of Saccharomyces cerevisiae cell lysate in the diet of laying hens increased egg weight, egg production, and improved feed conversion ${ }^{54}$. The authors also attributed these improvements to the characteristics of yeast cell wall components, which bind to the cell surface of some bacteria and prevent colonization, reducing the load of bacterial pathogens in the gut, which allows to the nutrients to be 


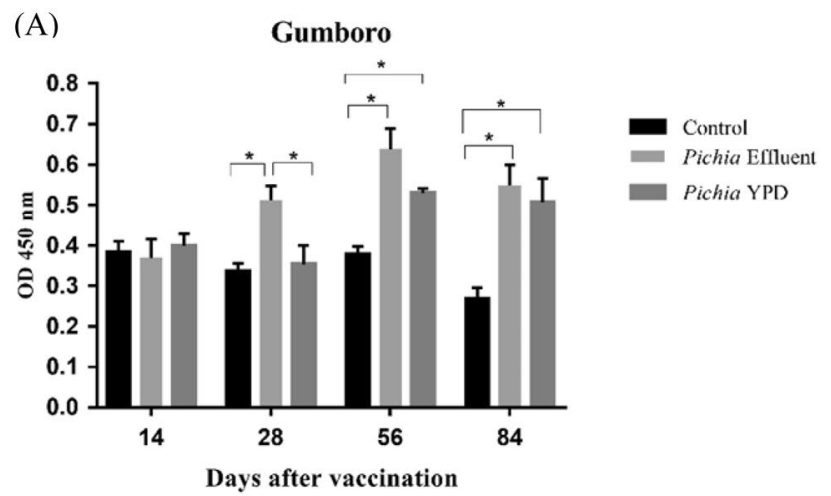

\section{(B) \\ Infectious Bronchitis}

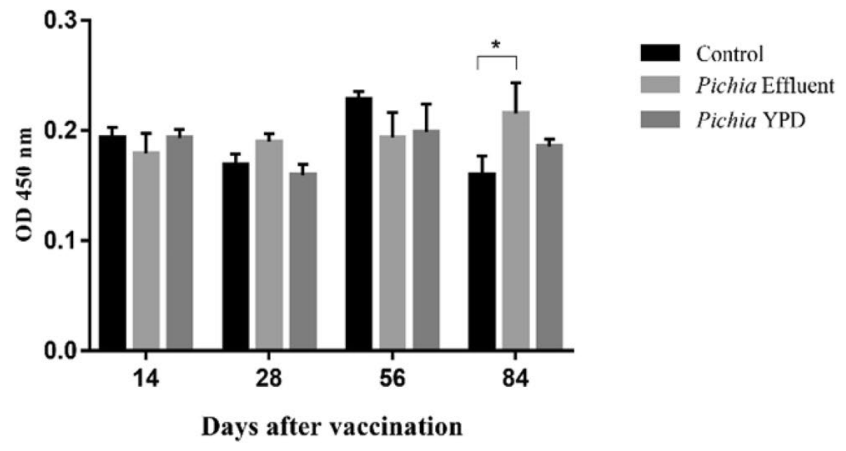

(C) Newcastle

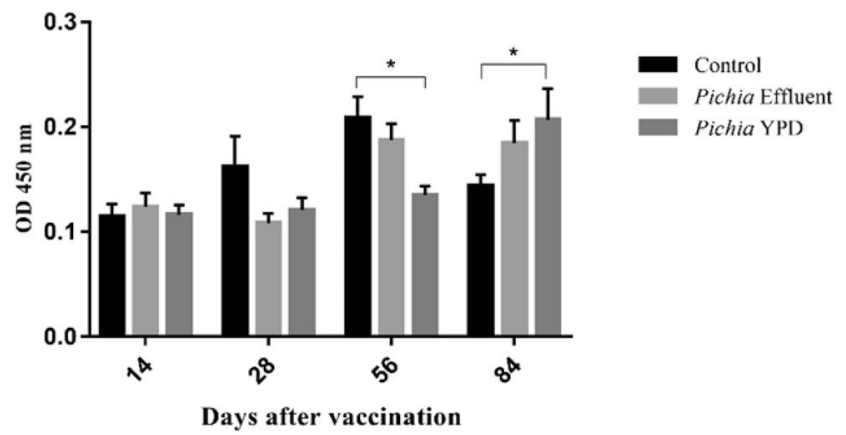

Figure 1. Evaluation by ELISA of antibodies anti - Gumboro disease (A), anti - Avian Infectious Bronchitis (B) and anti - Newcastle (C) of quails vaccinated against these diseases and fed diets containing P. pastoris X-33 grown in parboiled rice effluent supplemented with biodiesel glycerol or in YPD medium. Control=basal diet; Pichia Effluent $=$ basal diet + P. pastoris $\mathrm{X}-33$ grown in parboiled rice effluent supplemented with biodiesel glycerol; Pichia $\mathrm{YPD}=$ basal diet + P. pastoris $\mathrm{X}-33$ grown in YPD medium. *Significant difference between averages $(P<0.05)$ by Tukey's test.

\begin{tabular}{|l|l|l|l|l|l|}
\hline Days after vaccination & Control & Pichia Effluent & Pichia YPD & SEM & $P$-value \\
\hline $14 \mathrm{~d}$ & 2.75 & 2.75 & 2.5 & 0.083 & 0.9499 \\
\hline $28 \mathrm{~d}$ & 2.0 & 2.75 & 3.0 & 0.300 & 0.5785 \\
\hline $56 \mathrm{~d}$ & 5.0 & 4.25 & 4.5 & 0.220 & 0.4355 \\
\hline $84 \mathrm{~d}$ & $4.25^{\mathrm{b}}$ & $6.0^{\mathrm{ab}}$ & $7.5^{\mathrm{a}}$ & 0.939 & 0.0097 \\
\hline
\end{tabular}

Table 5. Anti-NDV antibodies titer $\left(\log _{2}\right)$, obtained by hemagglutination inhibition test (HI), of quails vaccinated against Newcastle Disease (NDV) and fed diets containing P. pastoris X-33 grown in parboiled rice effluent supplemented with biodiesel glycerol or in YPD medium. Different superscript letters in the same row indicate significant difference between averages $(P<0.05)$ by Tukey's test; SEM $=$ Standard error of the mean. Control = basal diet; Pichia Effluent $=$ basal diet + P. pastoris $\mathrm{X}-33$ grown in parboiled rice effluent supplemented with biodiesel glycerol; Pichia $\mathrm{YPD}=$ basal diet + P. pastoris $\mathrm{X}-33$ grown in $\mathrm{YPD}$. 


\begin{tabular}{|c|c|c|c|c|c|c|}
\hline \multirow[b]{2}{*}{ Organ } & \multirow[b]{2}{*}{ Time } & \multicolumn{3}{|c|}{ Treatments } & \multirow[b]{2}{*}{ SEM } & \multirow[b]{2}{*}{$P$-value } \\
\hline & & Control & Pichia Effluent & Pichia YPD & & \\
\hline \multirow{4}{*}{ Heart } & $14 \mathrm{~d}$ & 0.80 & 0.83 & 0.78 & 0.015 & 0.8506 \\
\hline & $28 \mathrm{~d}$ & 0.70 & 0.72 & 0.83 & 0.038 & 0.1467 \\
\hline & $56 \mathrm{~d}$ & 0.74 & 0.77 & 0.80 & 0.019 & 0.5986 \\
\hline & $84 \mathrm{~d}$ & 0.65 & 0.75 & 0.76 & 0.035 & 0.4898 \\
\hline \multirow{4}{*}{ Liver } & $14 \mathrm{~d}$ & $2.55^{\mathrm{a}}$ & $1.94^{\mathrm{b}}$ & $2.13^{\mathrm{ab}}$ & 0.178 & 0.0431 \\
\hline & $28 \mathrm{~d}$ & 2.02 & 1.75 & 1.87 & 0.079 & 0.3935 \\
\hline & $56 \mathrm{~d}$ & 1.96 & 2.12 & 2.00 & 0.047 & 0.7308 \\
\hline & $84 \mathrm{~d}$ & 1.59 & 1.76 & 1.41 & 0.102 & 0.3911 \\
\hline \multirow{4}{*}{ Spleen } & $14 \mathrm{~d}$ & 0.08 & 0.06 & 0.08 & 0.008 & 0.3107 \\
\hline & $28 \mathrm{~d}$ & 0.05 & 0.05 & 0.04 & 0.004 & 0.5963 \\
\hline & $56 \mathrm{~d}$ & 0.07 & 0.09 & 0.05 & 0.012 & 0.2690 \\
\hline & $84 \mathrm{~d}$ & 0.06 & 0.06 & 0.04 & 0.007 & 0.4335 \\
\hline \multirow{4}{*}{ Bursa of Fabricius } & $14 \mathrm{~d}$ & 0.05 & 0.08 & 0.06 & 0.007 & 0.8043 \\
\hline & $28 \mathrm{~d}$ & 0.04 & 0.03 & 0.03 & 0.004 & 0.5121 \\
\hline & $56 \mathrm{~d}$ & 0.01 & 0.02 & 0.01 & 0.002 & 0.2955 \\
\hline & $84 \mathrm{~d}$ & 0.01 & 0.03 & 0.04 & 0.009 & 0.4206 \\
\hline \multirow{4}{*}{ Duodenum } & $14 \mathrm{~d}$ & $1.49^{\mathrm{a}}$ & $1.04^{\mathrm{b}}$ & $1.10^{\mathrm{b}}$ & 0.143 & 0.0295 \\
\hline & $28 \mathrm{~d}$ & 0.99 & 1.01 & 1.01 & 0.005 & 0.9888 \\
\hline & $56 \mathrm{~d}$ & 1.00 & 0.90 & 1.00 & 0.033 & 0.6906 \\
\hline & $84 \mathrm{~d}$ & $0.87^{\mathrm{a}}$ & $0.86^{\mathrm{ab}}$ & $0.72^{\mathrm{b}}$ & 0.051 & 0.0489 \\
\hline \multirow{4}{*}{ Ceca } & $14 \mathrm{~d}$ & 0.65 & 0.79 & 0.63 & 0.051 & \begin{tabular}{|l|l|}
0.7005 \\
\end{tabular} \\
\hline & $28 \mathrm{~d}$ & 0.43 & 0.49 & 0.61 & 0.052 & 0.3506 \\
\hline & $56 \mathrm{~d}$ & 0.55 & 0.49 & 0.68 & 0.055 & 0.3206 \\
\hline & $84 \mathrm{~d}$ & 0.57 & 0.51 & 0.48 & 0.026 & \begin{tabular}{|l|}
0.7299 \\
\end{tabular} \\
\hline
\end{tabular}

Table 6. Relative weight of organs ( $\mathrm{g} / 100 \mathrm{~g}$ body weight) of quails fed diets containing Pichia pastoris $\mathrm{X}-33$ grown in parboiled rice effluent supplemented with biodiesel glycerol or in YPD medium. Different superscript letters in the same row indicate significant difference between averages $(P<0.05)$ by Tukey's test; $\mathrm{SEM}=$ Standard error of the mean. Control = basal diet; Pichia Effluent = basal diet + P. pastoris X-33 grown in parboiled rice effluent supplemented with biodiesel glycerol; Pichia YPD = basal diet + P. pastoris X-33 grown in YPD medium.

\begin{tabular}{|c|c|c|c|c|c|c|}
\hline & \multirow[b]{2}{*}{ Time } & \multicolumn{3}{|c|}{ Treatments } & \multirow[b]{2}{*}{ SEM } & \multirow[b]{2}{*}{$P$-value } \\
\hline & & Control & Pichia Effluent & Pichia YPD & & \\
\hline \multirow{4}{*}{ Villus height $(\mu \mathrm{m})$} & $14 \mathrm{~d}$ & 982 & 1,026 & 1,008 & 8.56 & 0.0691 \\
\hline & $28 \mathrm{~d}$ & 997 & 1,040 & 1,018 & 7.80 & 0.1990 \\
\hline & $56 \mathrm{~d}$ & 1,013 & 1,034 & 1,036 & 9.50 & 0.4454 \\
\hline & $84 \mathrm{~d}$ & 1,052 & 1,065 & 1,069 & 9.95 & 0.8771 \\
\hline \multirow{4}{*}{ Crypt depth $(\mu \mathrm{m})$} & $14 \mathrm{~d}$ & 158 & 147 & 125 & 1.58 & 0.5547 \\
\hline & $28 \mathrm{~d}$ & 152 & 190 & 157 & 1.73 & 0.4891 \\
\hline & $56 \mathrm{~d}$ & 176 & 192 & 161 & 1.47 & 0.7159 \\
\hline & $84 \mathrm{~d}$ & 191 & 194 & 166 & 2.06 & 0.9330 \\
\hline
\end{tabular}

Table 7. Morphometric analysis of villus height and crypt depth in duodenum of quails fed diets containing Pichia pastoris X-33 grown in parboiled rice effluent supplemented with biodiesel glycerol or in YPD medium. Different superscript letters in the same row indicate significant difference between averages $(P<0.05)$ by Tukey's test; SEM = Standard error of the mean. Control = basal diet; Pichia Effluent = basal diet + P. pastoris $\mathrm{X}-33$ grown in parboiled rice effluent supplemented with biodiesel glycerol; Pichia YPD $=$ basal diet + P. pastoris $\mathrm{X}-33$ grown in YPD medium.

assimilated efficiently and targeted to egg production ${ }^{55,56}$. The yolk percentage did not increase with $P$. pastoris supplementation, reinforcing a pattern that had already been observed in studies using other probiotic species in laying hens $\mathrm{s}^{14,50}$ and in quails that received dry bakery yeast ${ }^{57}$.

Yolk color was not affected either by the inclusion of $P$. pastoris in the diets. Yolk coloration is influenced mostly by the deposition of dietary carotenoids, mainly from corn, in the egg yolk ${ }^{58}$. Since the corn percentage in the diet did not vary among the treatments, this result was expected. However, Mikulski et al. ${ }^{50}$ obtained a higher score in yolk color in probiotic-treated groups than in the control and proposed that probiotics may improve carotenoid absorption and deposition in the yolk. Even so, our result is considered positive, since it suggests 
that the yeast can be used to improve the immune status of the birds without affecting the yolk color, which is an important factor for consumer acceptance of the product.

The Haugh Unit is generally used to evaluate albumen quality, which in turn is closely linked to egg freshness. Albumen quality is most influenced by factors as lineage, age of the animals, and egg storage time ${ }^{58}$, whereas nutritional characteristics seem do not influence in $\mathrm{HU}^{59}$, as seen in the present study with $P$. pastoris supplementation.

The results of this work confirmed data reported in the literature that probiotics increment or modulate the immune response ${ }^{60,61}$. The analysis showed that supplementation of the quail diet with $P$. pastoris enhanced the anti-NDV, anti-IBV, and anti-Gumboro immune responses. Indirect ELISA and HI showed the same trends on quantification of anti-NDV antibodies. In both tests, sera on day 84 exhibited an increase of up to $76 \%$ in the anti-NDV response in the Pichia YPD group compared to the control. Kasmani et al..$^{28}$ reported an increase of $82 \%$ in the anti-NDV titer when Brevibacillus laterosporus was included in the quail diet, and they recently reported that quails fed with a diet containing a commercial probiotic consortium had an anti-NDV titer twice higher than the control group ${ }^{29}$. In relation to IBV, treatments with $P$. pastoris minimally stimulated the production of specific antibodies, with an increase of 35\% in the Pichia Effluent group relative to the control group at 84 days. This result reflects observations in broilers, in which anti-IBV titers in groups treated with probiotics did not differ significantly from the other groups ${ }^{62,63}$, although the probiotic Lactobacillus casei caused immunomodulatory activity in the anti-IBV response of laying hens ${ }^{64}$.

Production of anti-Gumboro antibodies was higher in the Pichia Effluent group ( $<<0.05)$, with an increase of $52 \%$ at 28 days, $69 \%$ at 56 days, and $104 \%$ at 84 days relative to the control group. Similarly, Gil de los Santos et al. ${ }^{22}$ confirmed the immunomodulatory activity of $P$. pastoris produced in this same effluent, which generated in broilers, a higher anti-Gumboro antibodies titer than the control at 28 days. The same author had already demonstrated the potential of $P$. pastoris X-33 as a bioremediator microorganism, finding that the yeast grown in parboiled rice effluent supplemented with $15 \mathrm{~g} . \mathrm{L}^{-1}$ of biodiesel glycerol promoted reductions in COD - chemical oxygen demand (55\%), phosphorus (52\%), and nitrogen $(45 \%)^{23}$. Recently, the cultivation of the probiotic Saccharomyces boulardii in this effluent reduced COD, nitrogen and phosphorus concentrations, reinforcing the possibility of producing probiotic yeasts in effluent and simultaneously reducing the environmental parameters ${ }^{65}$. These combined results bring a new approach to $P$. pastoris, which has been used for decades as a heterologous system for protein expression ${ }^{16}$.

The relative weights of the heart, spleen, bursa of Fabricius, and cecal tonsils did not vary with the addition of $P$. pastoris X-33, in concurrence with observations of of Lactobacillus spp. consumption by broilers ${ }^{66,67}$ and quails ${ }^{29}$. The two groups fed with $P$. pastoris had lower relative duodenum weights than the control group on day $14(\mathrm{p}<0.05)$. The literature reports controversial findings on the liver weight; some studies indicate that probiotics increase liver weight ${ }^{45,68}$ while others do not demonstrate the influence of probiotics ${ }^{29,67,69}$. Contrary to these reports, the group supplemented with $P$. pastoris grown in effluent had a lower average in the relative liver weight than the control group on day 14 . According to Kalavathy et al. ${ }^{66}$, the presence of hepatomegaly may indicate infection, which was not noted in any treatment, showing that $P$. pastoris did not cause adverse effects during the whole period of administration. In addition, although the Pichia Effluent group had the highest values of weight gain, no hepatic degeneration or lesions were observed in any of the livers.

In this study, no negative effects of $P$. pastoris were observed on the analyzed parameters, nor any lesion was found in the liver or intestine, regardless of the medium in which the yeast was cultured. These data highlight the innocuous profile of $P$. pastoris, reinforcing previous results in broilers and mice ${ }^{20-22}$. A prior study indicated that the residual biomass of black tea production, composed of Pichia sp. NRRL Y-4810 in consortium with two other microorganisms, had beneficial probiotic effects in broilers without causing toxicity or hepatic alterations ${ }^{70}$. In the present study, in the variables in which $P$. pastoris had no superior effect relative to the control, had also no harmful effect, showing that the yeast can be used to increase immunity without impairing the important productive aspects of the quails.

In general, $P$. pastoris grown in effluent supplemented with biodiesel glycerol promoted more benefits in terms of immune status and weight gain, whereas $P$. pastoris grown in YPD improved some egg quality variables. This same trend was observed in broiler chickens, in which $P$. pastoris cultivated in effluent supplemented with biodiesel glycerol induced immunomodulatory effect, while the same yeast grown in YPD improved feed conver$\operatorname{sion}^{22}$. Our group attributed this to the difference in the composition of the culture medium, which could offer distinct nutrients for the yeast, changing its cellular composition mainly in the cell wall and thereby promoting different interactions with host intestinal mucosa, as has been shown in some studies. As previously suggested, this contrast may be related to the differences in nutrient composition between the culture media ${ }^{71}$. Researchers verified that glycerol may be a carbon source in cultivations of yeasts, enhancing the polysaccharides and mannoprotein contents in the cell wall ${ }^{72}$. They also tested waste potato juice water and glycerol as culture medium for four $S$. cerevisiae strains and detected a modification in the cell wall thickness and changes in the concentrations of mannoproteins and $\beta$-glucans ${ }^{73}$. Yeast cell wall mannoproteins act as nonspecific modulators of the immune system and their biological activity may include adjuvant effects ${ }^{74}$ and stimulation of phagocytic activity in macrophages as well as potentiation of synthesis and release of inflammatory mediators as TNF- $\alpha$ and nitric oxide ${ }^{75}$. For these reasons, it is suggested that, due to the diverse composition from the YPD medium, effluent and glycerol can promote differentiated formation of the yeast cell wall, resulting in a unique stimulation of the mucosal immune system. However, analyses of cell wall composition should be performed in the future to prove this effect.

Finally, it is important to note that in most variables, the probiotic effect of $P$. pastoris did not manifest until 84 days, revealing its benefits mainly at the end of experiment. At this time, the more pronounced response to probiotic supplementation probably was attributable to cumulative stress caused by manipulation during the weighing and data collections, long housing period in cages, and decreasing in cage space due to the increase in body size of birds. The poultry sensibility to various stress conditions, such as transport, catching, caging, handling, temperature changes, disturbance, and noise, can affect their performance, cause injury, and even lead to death ${ }^{76}$. The 
use of probiotics in broiler diets has been shown to alleviate some effects of thermal stress ${ }^{77,78}$ and overcrowding ${ }^{79}$. These studies corroborate what was previously discussed in the present work: the benefits of probiotic supplementation are more evident when the animal is subjected to some type of adverse condition.

In conclusion, Pichia pastoris X-33 produced in YPD, when used as a supplement in quail diets caused increased egg weight. When produced in parboiled rice effluent and biodiesel glycerol, $P$. pastoris X-33 had an immunomodulatory effect, enhancing the humoral response to the vaccine against NDV, IBV and Gumboro, without negatively affecting the productive parameters and without causing alterations in the internal organs. The possibility of producing $P$. pastoris X-33 from industrial effluents and by-products makes this yeast an interesting probiotic option for poultry farming.

\section{Materials and Methods}

Pichia pastoris X-33 cultivation. The yeast P. pastoris strain X-33 (Invitrogen, USA) was cultured in two distinct culture media: commercial medium Yeast Extract-Peptone-Dextrose (YPD: $1 \%$ yeast extract, $2 \%$ peptone, $2 \%$ dextrose) and an alternative medium composed of parboiled rice effluent $+15 \mathrm{~g} . \mathrm{L}^{-1}$ of crude glycerol, a by-product of the biodiesel industry, both prepared in laboratory. Commercial culture medium (YPD) was prepared from dilution of the powder YPD medium commercialized by HiMedia (HiMedia ${ }^{\mathrm{TM}}$ Laboratories Pvt Ltd). The alternative medium was prepared using effluent from rice parboiling tanks, provided with no costs by a local rice processing industry, and glycerol provided with no costs by a regional soybean biodiesel industry. After preparation, both media were sterilized. The inoculum was produced in YPD medium at $28^{\circ} \mathrm{C}$ for $24 \mathrm{~h}$ in an orbital shaker at $180 \mathrm{rpm}$. Two yeast cultivations were performed in each medium, with $700 \mathrm{~mL}$ of inoculum added to $6.3 \mathrm{~L}$ of medium in a bench bioreactor (Bioflo 110 , New Brunswick) at $28^{\circ} \mathrm{C}, 500 \mathrm{rpm}, 1 \mathrm{vvm}$ of air, for 24 hours. The $\mathrm{pH}$ was adjusted to 5.5 with $1 \mathrm{M} \mathrm{NaOH}$, and antifoam (Antifoam 204, Sigma) was added to the cultures to avoid excessive foaming as a result of stirring. After cultivation, cells were recovered by centrifugation at $4,000 \mathrm{rpm}$ for 15 minutes and then washed three times with $0.9 \%$ saline solution. Viable cells of $P$. pastoris X-33 were quantified by plating serial dilutions in YM Agar and counting of colony forming units (CFU.mL ${ }^{-1}$ ) after incubation at $28^{\circ} \mathrm{C}$ for $48 \mathrm{~h}$.

Animals and housing conditions. In total, 106 forty-days-old female quails, from a Coturnix coturnix coturnix lineage, were used in the experiment. The animals belonged to a dual purpose lineage developed in Federal University of Pelotas, which has good performance on both egg productivity and meat production. The quails were housed in metal cages, in a room with controlled temperature around $25^{\circ} \mathrm{C}$ and cycles of $17 \mathrm{~h}$ of light and $7 \mathrm{~h}$ of darkness. During the experimental period, the birds received water ad libitum and the feed was provided daily.

Ethical approval statement. The procedures and activities performed in this experiment were approved by Federal University of Pelotas Committee on Animal Research and Ethics, protocol $n^{\circ} 6848$, in agreement with the Brazilian legislation, relevant guidelines and regulations, following all the ethical precepts of animal experimentation.

Experimental design. The experiment lasted for 84 days, divided into three consecutive cycles of 28 days each. Birds were previously weighed and distributed among the treatments according to their weights, in order to maintain the homogeneity among treatments above $80 \%$.

Treatments. The birds were divided into three treatments, with 16 repetitions each: T1 (Control): Vaccinated animals that received basal diet without yeast; T2 (Pichia Effluent): Vaccinated animals receiving a basal diet supplemented with Pichia pastoris produced in parboiled rice effluent supplemented with biodiesel glycerol, and T3 (Pichia YPD): Vaccinated animals receiving a basal diet supplemented with Pichia pastoris produced in YPD medium. The repetitions consisted of an experimental unit of two quails, and each repetition was allocated in an individual metal cage. A separated group of 10 animals did not receive the vaccines and served as a control for immunomodulation assays. These animals received basal diet without yeast and were housed under the same conditions as the treatment groups throughout the experimental period.

Experimental diets. A basal diet without antimicrobials was formulated specifically to meet the nutritional needs of the quails, according to the recommendations ${ }^{80}$, as shown in Table 8 . The diets were isocaloric, isoproteic and isovitaminic, differing only by the addition "on top" of P. pastoris X-33, in the concentration of $1 \times 10^{7} \mathrm{CFU}$. $\mathrm{g}^{-1}$, in T2 and T3. Yeast was mixed into the diet weekly, followed by quantification to assess cell viability and confirm the appropriate concentration. After preparation, the diets were stored in individual containers for each repetition, so that feed consumption per repetition could be better controlled.

Vaccination. On day one of the experiment, the birds were vaccinated with the New-Bronk-Gumbor (Biovet ${ }^{\circledR}$ ) vaccine against Newcastle Disease, Infectious Bronchitis, and Gumboro Disease. In each bird was administered a dose of $0.25 \mathrm{~mL}$ intramuscularly in the chest muscle. After 28 days, the birds were revaccinated with the same dose.

Performance. The following performance parameters were evaluated: weight gain, feed intake, egg production, and feed conversion. The birds were weighed at the beginning of the experimental period and at the end of each cycle. Egg weight was determined weekly and egg laying of each animal was noted daily to calculate the egg production $(\mathrm{P})$ according to the formula: $\mathrm{P}(\%)=($ total number of eggs produced in the cycle $\times 100) /$ number of days of the cycle. The feed intake in each experimental unit was determined weekly by the difference between the amount of diet provided for seven days and the leftover at the end of this period. The egg mass was calculated by 


\begin{tabular}{|l|l|}
\hline Ingredient & Content (\%) \\
\hline Corn, grain & 44.60 \\
\hline Soybean meal & 40.38 \\
\hline Limestone & 5.83 \\
\hline Vitamin mineral mix ${ }^{\mathrm{b}}$ & 5.00 \\
\hline Soybean oil & 2.50 \\
\hline Dicalcium Phosphate & 1.20 \\
\hline DL-Methionine & 0.22 \\
\hline Sodium chloride & 0.18 \\
\hline L-Lysine HCl & 0.08 \\
\hline Nutrient Composition & \\
\hline ME (kcal/kg) & \\
\hline CP (\%) & 2805 \\
\hline Digestible lysine (\%) & 21.98 \\
\hline Digestible methionine (\%) & 1.18 \\
\hline Digestible methionine + cysteine (\%) & 0.50 \\
\hline Available phosphorus (\%) & 0.80 \\
\hline Calcium (\%) & 0.34 \\
\hline Sodium (\%) & 3.50 \\
\hline Chloride (5) & 0.24 \\
\hline Threonine (\%) & 0.15 \\
\hline Tryptophan (\%) & 0.75 \\
\hline & 0.26 \\
\hline
\end{tabular}

Table 8. Composition of basal diet. ${ }^{\mathrm{a}} \mathrm{ME}=$ metabolizable energy; $\mathrm{CP}=$ crude protein. ${ }^{\mathrm{b}} \mathrm{Composition}$ per kilogram of product: zinc: $1535 \mathrm{mg}$; manganese: $1485 \mathrm{mg}$; iron: $1695 \mathrm{mg}$; iodine: $29 \mathrm{mg}$; copper: $244 \mathrm{mg}$; selenium: 3,2 mg; calcium: 197,5 g; cobalt: 5,1 mg; fluoride: $400 \mathrm{mg}$; phosphorus: $50 \mathrm{~g}$; methionine: $11 \mathrm{~g}$; vitamin E: $540 \mathrm{mg}$; vitamin B1: $40 \mathrm{mg}$; vitamin B6: $54 \mathrm{mg}$; vitamin K3: 51,5 mg; vitamin B12: $430 \mathrm{mcg}$; vitamin A: 207,000 IU; vitamin D3: 43,200 IU; vitamin B2: $120 \mathrm{mg}$; pantothenic acid: 204,6 mg; choline: $320 \mathrm{mg}$; biotin: 1,4 mg; folic acid: $16,7 \mathrm{mg}$; nicotinic acid: $840 \mathrm{mg}$.

the formula: Egg mass = (Average egg weight $\times$ egg production $) / 100$. For egg weight, two eggs of each experimental unit were weighed once a week, and from these values, the week average of egg weight of the treatments was calculated and then the average for each 28-day cycle was performed from the week values. Feed conversion per egg mass was defined by the ratio between feed intake and egg mass ( $\left.\mathrm{g} \cdot \mathrm{g}^{-1}\right)$.

Egg quality. In the last three days of each cycle, eggs were collected for external and internal quality analysis. Two eggs per experimental unit were chosen randomly to be used in the analyses.

External quality. The eggs were weighed individually on a digital scale with a precision of $0.01 \mathrm{~g}$. To measure the specific gravity, a variable related to egg shell quality, the eggs were placed in successive containers with solutions of increasing concentrations of sodium chloride $(\mathrm{NaCl})$ until they floated. The density at which the flotation occurred was noted for each egg $^{81}$. The eggs were then broken, and the shells were washed, dried at room temperature for 72 hours, and weighed individually on an analytical digital scale with a precision of $0.0001 \mathrm{~g}$. The eggshell percentage was calculated as the eggshell weight multiplied by 100 and divided by the egg weight. The eggshell thickness was measured in the equatorial region of the egg using a digital micrometer (Digimess ${ }^{\circledR}$ ) with a precision of $0.001 \mathrm{~mm}^{82}$.

Internal quality. The opened eggs were placed individually in Petri dishes. Yolk color was evaluated visually with a yolk color fan $\left(\mathrm{DSM}^{\circledR}\right)$ containing a 15-tone color scale ranging from 1 (light yellow) to 15 (orange-red). Yolk coloration was also analyzed using a portable digital colorimeter (Minolta ${ }^{\circledR}$ ) according to the methodology proposed by Honikel ${ }^{83}$ for quantification of the parameters: $\mathrm{L}^{*}$ (lightness), $\mathrm{a}^{*}$, and $\mathrm{b}^{*}$. The $\mathrm{a}^{*}$ value involves the color component that varies from red $\left(+\mathrm{a}^{*}\right)$ to green $\left(-\mathrm{a}^{*}\right)$, the $\mathrm{b}^{*}$ value varies from yellow $\left(+\mathrm{b}^{*}\right)$ to blue $\left(-\mathrm{b}^{*}\right)$, and the $\mathrm{L}^{*}$ value varies from white $(\mathrm{L}=100)$ to black $(\mathrm{L}=0)$.

The Haugh unit was obtained from the formula described by $\mathrm{Haugh}^{84}: \mathrm{UH}=100 \times \log \left(\mathrm{H}+7,57-1,7 \times \mathrm{W}^{0,37}\right)$, where $\mathrm{H}=$ albumen height and $\mathrm{W}=$ egg weight. For this, the albumen height was measured with a manual pachymeter. The yolk and albumen weights were determined with a precision digital scale, and then multiplied by 100 and divided by the egg weight to determine the yolk and albumen percentages, respectively.

Intestinal morphometry, organ weights and safety. Four animals from each treatment were slaughtered on days 14, 28, 56, and 84 of the experiment. After 24 hours of fasting, the quails were euthanized, eviscerated, and the heart, liver, spleen, bursa of Fabricius, cecal tonsils, and duodenum were collected whole and weighed on an analytical digital scale. Liver portions and $2 \mathrm{~cm}$ sections of the duodenum were fixed in a $10 \%$ formalin solution for $48 \mathrm{~h}$ and subsequently dehydrated by successive washes with ethyl alcohol in increasing concentrations $(70 \%, 80 \%, 90 \%$, and absolute). After dehydration, the samples were diaphanized in xylol, followed 
by inclusion in paraffin blocks, which were cut with a microtome in 12 transverse and semi-seriated cuts with a thickness of $5 \mu \mathrm{m}$. The blades were stained with hematoxylin-eosin and covered with coverslips. The livers were analyzed for the presence of lesions, while the morphometry of duodenums was evaluated using image capture and measurement of villus height and crypt depth with Image Pro-Plus 4.5 software (Media Cybernetics, Silver Spring, MD).

Humoral immune response. Blood samples were collected from animals to be slaughtered on days 14, 28, 56 and 84 to quantify antibodies to the New-Bronk-Gumbor $\left(\right.$ Biovet $\left.^{\circledR}\right)$ vaccine by indirect ELISA. Blood samples from non-vaccinated animals were also collected and tested, as a control of the assay. Monovalent vaccines against Newcastle disease (New-Vacin La Sota), Infectious Bronchitis (Bio-Bronk-Vet H-120), and Gumboro disease (Gumbor-Vet) were used as antigen. All the 96-well microtiter plates were coated with two doses of vaccine per well, resuspended in carbonate-bicarbonate buffer ( $\mathrm{pH} 9.6)$, and incubated overnight at $4^{\circ} \mathrm{C}$. After washing with PBS-T, sera were diluted 1:50, added in triplicate, and incubated for $1 \mathrm{~h}$ at $37^{\circ} \mathrm{C}$. Specific antibodies were detected with the peroxidase-conjugated anti-chicken secondary antibody, diluted 1:2000. After washing with PBS-T, chromogenic substrate was added, and the absorbances were quantified with spectrophotometer at $450 \mathrm{~nm}$.

Hemagglutination inhibition test. The antibody titer against Newcastle disease virus (NDV) was determined from the sera of days $14,28,56$, and 84 by the hemagglutination inhibition (HI) test, according to the standard protocol ${ }^{85}$. Sera of the non-vaccinated animals were also tested, as a control of the assay. Initially, a hemagglutination test was performed to determine the dilution corresponding to four hemagglutinating units (4 HAU) of the virus. One HAU is considered the reciprocal of the highest dilution in which occurred complete agglutination of a $1 \%$ suspension of chicken erythrocytes. For the HI test, $25 \mu \mathrm{L}$ of sera were added to microplates containing $25 \mu \mathrm{L} /$ well of PBS for base- 2 serial dilutions, up to 1:4096. Four HAUs of the virus were loaded into each well, and after 30 minutes of incubation, $25 \mu \mathrm{L}$ of a $1 \%$ suspension of chicken erythrocytes were added to the wells. The plate was incubated at rest at room temperature for 30 minutes to allow the sedimentation of the erythrocytes. The titer of each serum was expressed as the $\log _{2}$ of the reciprocal of the highest serum dilution which inhibited the hemagglutinating activity of NDV.

Statistical analysis. To verify the effects of yeast and quail age on performance and egg quality variables, statistical analysis was performed according to a completely randomized design with time-repeated measures using the Mixed procedure and Compound Symmetry covariance matrix structure. After analysis of variance (ANOVA), the LSM (Least Squares Means) test was performed, with the comparison of means adjusted by the Tukey-Kramer test. In the results of intestinal morphometry and antibody quantification, the Statistix 9 software was used to perform ANOVA and Tukey test to determine the significance levels between the means of the treatments. All statistical tests were performed with a significance level of $\mathrm{P}<0.05$.

\section{Data availability}

The authors declare that materials, data and associated protocols are promptly available to readers without restrictions. Readers can obtain materials and information under request, contacting the corresponding author.

Received: 8 February 2019; Accepted: 7 October 2019;

Published online: 25 October 2019

\section{References}

1. Cheng, G. et al. Antibiotic alternatives: the substitution of antibiotics in animal husbandry? Front. Microbiol. 5, 217 (2014).

2. Castanon, J. I. R. History of the use of antibiotic as growth promoters in European poultry feeds. Poult. Sci. 86, 2466-2471 (2007)

3. Stanton, T. B. A call for antibiotic alternatives research. Trends in Microbiol. 21, 111-113 (2013).

4. Gadde, U., Kim, W. H., Oh, S. T. \& Lillehoj, H. S. Alternatives to antibiotics for maximizing growth performance and feed efficiency in poultry: a review. Anim. Health Res. Rev. 18, 26-45 (2017).

5. Huyghebaert, G., Ducatelle, R. \& Van Immerseel, F. An update on alternatives to antimicrobial growth promoters for broilers. Vet. J. 187, 182-188 (2011).

6. Seal, B. S., Lillehoj, H. S., Donovan, D. M. \& Gay, C. G. Alternatives to antibiotics: a symposium on the challenges and solutions for animal production. Anim. Health Res. Rev. 14, 78-87 (2013).

7. Shahravy, A., Tabandeh, F., Bambai, B., Zamanizadeh, H. \& Mizani, M. Optimization of probiotic Lactobacillus casei ATCC 334 production using date powder as carbon source. Chem. Ind. \& Chem. Eng. Quart. 18, 273-82 (2012).

8. Manzoor, A., Qazi, J. I., Haq, I., Mukhtar, H. \& Rasool, A. Significantly enhanced biomass production of a novel bio-therapeutic strain Lactobacillus plantarum (AS-14) by developing low cost media cultivation strategy. J. Biol. Eng. 11, 17 (2017).

9. Food and Agriculture Organization/World Health Organization. Guidelines for the evaluation of probiotics in food. FAO/WHO (2002).

10. Coppola, M. M., Conceição, F. R. \& Gil-Turnes, C. Effect of Saccharomyces boulardii and Bacillus cereus var. toyoii on the humoral and cellular response of mice to vaccines. Food Agric. Immunol. 16, 213-219 (2005).

11. Gil de los Santos, J. R., Storch, O. B. \& Gil-Turnes, C. Bacillus cereus var. toyoii and Saccharomyces boulardii increased feed efficiency in broilers infected with Salmonella enteritidis. Br. Poult. Sci. 46, 494-497 (2005).

12. Lessard, M. et al. Administration of Pediococcus acidilactici or Saccharomyces cerevisiae boulardii modulates development of porcine mucosal immunity and reduces intestinal bacterial translocation after Escherichia coli challenge. J. Anim. Sci. 87, 922-934 (2009).

13. Zhang, J. L. et al. Different combinations of probiotics improve the production performance, egg quality, and immune response of layer hens. Poult. Sci. 91, 2755-2760 (2012).

14. Forte, C. et al. Effects of dietary Lactobacillus acidophilus and Bacillus subtilis on laying performance, egg quality, blood biochemistry and immune response of organic laying hens. J. Anim. Physiol. Anim. Nutr. 100, 977-87 (2016).

15. Guo, J. R., Dong, X. F., Liu, S. \& Tong, J. M. Effects of long-term Bacillus subtilis CGMCC 1.921 supplementation on performance, egg quality, and fecal and cecal microbiota of laying hens. Poult. Sci. 96, 1280-1289 (2017).

16. Cregg, J. M., Cereghino, J. L., Shi, J. \& Higgins, D. R. Recombinant protein expression in Pichia pastoris. Mol. Biotechnol. 16, 23-52 (2000). 
17. Gurkan, C. \& Ellar, D. J. Recombinant production of bacterial toxins and their derivatives in the methylotrophic yeast Pichia pastoris. Microb. Cell Fact. 4, 33-40 (2005).

18. Ahmad, M., Hirz, M., Pichler, H. \& Schwab, H. Protein expression in Pichia pastoris: recent achievements and perspectives for heterologous protein production. Appl. Microbiol. Biotechnol. 98, 5301-5317 (2014).

19. Roohvand, F., Shokri, M., Abdollahpour-Alitappeh, M. \& Ehsani, P. Biomedical applications of yeast - a patent view, part one: yeasts as workhorses for the production of therapeutics and vaccines. Expert Opin. Ther. Pat. 27, 929-951 (2017).

20. França, R. C. et al. Pichia pastoris X-33 has probiotic properties with remarkable antibacterial activity against Salmonella Typhimurium. Appl. Microbiol. Biotechnol. 99, 7953-61 (2015).

21. Gil de Los Santos, J. R., Storch, O. B., Fernandes, C. G. \& Gil-Turnes, C. Evaluation in broilers of the probiotic properties of Pichia pastoris and a recombinant P. pastoris containing the Clostridium perfringens alpha toxin gene. Vet. Microbiol. 156, 448-451 (2012).

22. Gil de los Santos, D. et al. Probiotic effect of Pichia pastoris X-33 produced in parboiled rice effluent and YPD medium on broiler chickens. PLoS ONE 13, e0192904, https://doi.org/10.1371/journal.pone.0192904 (2018).

23. Gil de Los Santos, D., Gil-Turnes, C. \& Conceição, F. R. Bioremediation of parboiled rice effluent supplemented with biodieselderived glycerol using Pichia pastoris X-33. Sci. World J. 2012, 492925, https://doi.org/10.1100/2012/492925 (2012).

24. Faitarone, A. B. G. et al. Economic traits and performance of italian quails reared at different cage stocking densities. Brazil. J. Poult. Sci. 7, 19-22 (2005)

25. Pastore, S. M., Oliveira, W. P. \& Muniz, J. C. L. Panorama da coturnicultura no Brasil. Nutritime 9, 2041-2049, https://www. nutritime.com.br/biblioteca-nutritime/ (2012).

26. Santos, T. C., Murakami, A. E., Fanhani, J. C. \& Oliveira, C. A. L. Production and reproduction of egg- and meat-type quails reared in different group sizes. Brazil. J. Poult. Sci. 13, 9-14 (2011).

27. Rahman, A. N. M. A., Hoque, M. N., Talukder, A. K. \& Das, Z. C. A survey of Japanese quail (Coturnix coturnix japonica) farming in selected areas of Bangladesh. Vet. World 9, 940-947 (2016).

28. Kasmani, F. B., Karimi, T., Allameh, A. \& Shariatmadari, F. A novel aflatoxin-binding Bacillus probiotic: Performance, serum biochemistry, and immunological parameters in Japanese quail. Poult. Sci. 91, 1846-1853 (2012).

29. Kasmani, F. B. \& Mehri, M. Effects of a multi-strain probiotics against aflatoxicosis in growing Japanese quails. Livest. Sci. 177, $110-116(2015)$

30. Seifi, K., Torshizi, M. A. K., Rahimi, S. \& Kazemifard, M. Efficiency of early, single-dose probiotic administration methods on performance, small intestinal morphology, blood biochemistry, and immune response of Japanese quail. Poult. Sci. 00, 1-8 (2017).

31. Gaggìa, F., Mattarelli, P. \& Biavati, B. Probiotics and prebiotics in animal feeding for safe food production. Int. J. Food Microbiol. 141, S15-S28 (2010).

32. Badia, R. et al. $\beta$-Galactomannan and Saccharomyces cerevisiae var. boulardii modulate the immune response against Salmonella enterica Serovar Typhimurium in porcine intestinal epithelial and dendritic cells. Clin. Vaccine Immunol. 19, 368-376 (2012).

33. Chaucheyras-Durand, F. \& Durand, H. Probiotics in animal nutrition and health. Benef. Microbes 1, 3-9 (2010).

34. Uyeno, Y., Shigemori, S. \& Shimosato, T. Effect of probiotics/prebiotics on cattle health and productivity. Microbes Environ. 30 , 126-132 (2015)

35. Apás, A. L., Arena, M. E., Colombo, S. \& González, S. N. Probiotic administration modifies the milk fatty acid profile, intestinal morphology, and intestinal fatty acid profile of goats. J. Dairy Sci. 98, 47-54 (2015).

36. Deng, Q. et al. Intravaginal probiotics modulated metabolic status and improved milk production and composition of transition dairy cows. J. Anim. Sci. 94, 760-70 (2016).

37. Golić, N. et al. In vitro and in vivo antagonistic activity of new probiotic culture against Clostridium difficile and Clostridium perfringens. BMC Microbiol. 17, 108 (2017).

38. Line, J. E., Bailey, J. S., Cox, N. A., Stern, N. J. \& Tompkins, T. Effect of yeast-supplemented feed on Salmonella and Campylobacter populations in broilers. Poult. Sci. 77, 405-410 (1998).

39. Santini, C. et al. Characterization of probiotic strains: An application as feed additives in poultry against Campylobacter jejuni. Int. J. Food Microbiol. 141, S98-S108 (2010).

40. Tellez, G., Pixley, C., Wolfenden, R. E., Layton, S. L. \& Hargis, B. M. Probiotics/direct fed microbials for Salmonella control in poultry. Food Res. Int. 45, 628-633 (2012).

41. Jayaraman, S. et al. Bacillus subtilis PB6 improves intestinal health of broiler chickens challenged with Clostridium perfringensinduced necrotic enteritis. Poult. Sci. 92, 370-374 (2013).

42. Kuritza, L. N., Westphal, P. \& Santin, E. Probiotics on poultry production. Ciência Rural 44, 1457-1465 (2014).

43. Wang, W. et al. Dietary live yeast and mannan-oligosaccharide supplementation attenuate intestinal inflammation and barrier dysfunction induced by Escherichia coli in broilers. Br. J. Nutr. 116, 1878-1888 (2016).

44. Lyons, T. P. Probiotics: an alternative to antibiotics. Pig News Info 8, 157-164 (1987).

45. Jin, L. Z., Ho, Y. W., Abdullah, N., Ali, M. A. \& Jalaludin, S. Effects of adherent Lactobacillus cultures on growth, weight of organs and intestinal microflora and volatile fatty acids in broilers. Anim. Feed Sci. Technol. 70, 197-209 (1998).

46. Biloni, A. et al. Evaluation of effects of EarlyBird associated with FloraMax-B11 on Salmonella Enteritidis, intestinal morphology, and performance of broiler chickens. Poult. Sci. 92, 2337-2346 (2013).

47. Cao, G. T. et al. Effects of a probiotic, Enterococcus faecium, on growth performance, intestinal morphology, immune response, and cecal microflora in broiler chickens challenged with Escherichia coli K88. Poult. Sci. 92, 2949-2955 (2013).

48. Abudabos, A. M., Alyemni, A. H. \& Al Marshad, M. B. A. Bacillus subtilis PB6 based-probiotic (CloSTAT ${ }^{\mathrm{TM}}$ ) improves intestinal morphology and microbiological status of broiler chickens under Clostridium perfringens challenge. Int. J. Agric. Biol. 15, 978-982 (2013).

49. Abdelqader, A., Irshaid, R. \& Al-Fataftah, A. R. Effects of dietary probiotic inclusion on performance, eggshell quality, cecal microflora composition, and tibia traits of laying hens in the late phase of production. Trop. Anim. Health Prod. 45, 1017-1024 (2013).

50. Mikulski, D., Jankowski, J., Naczmanski, J., Mikulska, M. \& Demey, V. Effects of dietary probiotic (Pediococcus acidilactici) supplementation on performance, nutrient digestibility, egg traits, egg yolk cholesterol, and fatty acid profile in laying hens. Poult. Sci. 91, 2691-2700 (2012).

51. Lei, K., Li, Y. L., Yu, D. Y., Rajput, I. R. \& Li, W. F. Influence of dietary inclusion of Bacillus licheniformis on laying performance, egg quality, antioxidant enzyme activities, and intestinal barrier function of laying hens. Poult. Sci. 92, 2389-2395 (2013).

52. Nahashon, S. N., Nakaue, H. S. \& Mirosh, L. W. Performance of Single Comb White Leghorn fed a diet supplemented with a live microbial during the growth and egg laying phases. Anim. Feed Sci. Technol. 57, 25-38 (1996).

53. Panda, A. K., Rao, S. S. R., Raju, M. V. L. N. \& Sharma, S. S. Effect of probiotic (Lactobacillus sporogenes) feeding on egg production and quality, yolk cholesterol and humoral immune response of White Leghorn layer breeders. J. Sci. Food Agric. 88, 43-47 (2008).

54. Yalçin, S., Yalçin, S., CCakin, K., Eltan, Ö. \& Dagaşan, L. Effects of dietary yeast autolysate (Saccharomyces cerevisiae) on performance, egg traits, egg cholesterol content, egg yolk fatty acid composition and humoral immune response of laying hens. J. Sci. Food Agric. 90, 1695-1701 (2010).

55. Spring, P., Wenk, C., Dawson, K. A. \& Newman, K. E. The effects of dietary mannanoligosaccharides on cecal parameters and the concentrations of enteric bacteria in the ceca of Salmonella-challenged broiler chicks. Poult. Sci. 79, 205-211 (2000).

56. Shashidhara, R. G. \& Devegowda, G. Effect of dietary mannanoligosaccharide on broiler breeder production traits and immunity. Poult. Sci. 82, 1319-1325 (2003). 
57. Yalçin, S., Erol, H., Ozsoy, B., Onbasilar, I. \& Yalçin, S. Effects of the usage of dried brewing yeast in the diets on the performance, egg traits and blood parameters in quails. Animal 2, 1780-1785 (2008).

58. Tang, S. G. H. et al. Chemical compositions of egg yolks and egg quality of laying hens fed prebiotic, probiotic, and synbiotic diets. J. Food Sci. 80, 1686-1695 (2015).

59. Williams, K. C. Some factors affecting albumen quality with particular reference to Haugh unit score. World's Poult. Sci. J. 48, 5-16 (1992).

60. Coppola, M. M. \& Gil-Turnes, C. Probiotics and immune response. Ciência Rural 34, 1297-1303 (2004).

61. Haghighi, H. R. et al. Modulation of antibody-mediated immune response by probiotics in chickens. Clin. Diagn. Lab. Immunol. 12, 1387-1392 (2005).

62. Khan, R. U., Rahman, Z. U., Javed, I. \& Muhammad, F. Effect of vitamins, protein level and probiotics on immune response of moulted male broiler breeders. J. Anim. Physiol. Anim. Nutr. 98, 620-627 (2014).

63. Alizadeh, M., Munyaka, P., Yitbarek, A., Echeverry, H. \& Rodriguez-Lecompte, J. C. Maternal antibody decay and antibodymediated immune responses in chicken pullets fed prebiotics and synbiotics. Poult. Sci. 96, 58-64 (2016).

64. Ogawa, T., Asai, Y., Sakamoto, H. \& Yasuda, K. Oral immunoadjuvant activity of Lactobacillus casei subsp. casei in dextran-fed layer chickens. Brit. J. Nutr. 95, 430-434 (2006).

65. Gaboardi, G. et al. Bioremediation and biomass production from the cultivation of probiotic Saccharomyces boulardii in parboiled rice effluent. J. Environ. Manage. 226, 180-186 (2018).

66. Kalavathy, R., Abdullah, N., Jalaludin, S. \& Ho, Y. W. Effects of Lactobacillus cultures on growth performance, abdominal fat deposition, serum lipids and weight of organs of broiler chickens. Brit. Poult. Sci. 44, 139-144 (2003).

67. Awad, W. A., Ghareeb, K., Abdel-Raheem, S. \& Böhm, J. Effects of dietary inclusion of probiotic and synbiotic on growth performance, organ weights, and intestinal histomorphology of broiler chickens. Poult. Sci. 88, 49-55 (2009).

68. Çakir, S. et al. Use of combined probiotic-prebiotic, organic acid and avilamycin in diets of Japanese quails. Revue Méd. Vét. 159, 565-569 (2008).

69. Chen, W., Wang, J. P., Yan, L. \& Huang, Y. Q. Evaluation of probiotics in diets with different nutrient densities on growth performance, blood characteristics, relative organ weight and breast meat characteristics in broilers. Br. Poult. Sci. 54, 635-41 (2013).

70. Murugesan, G. S., Sathishkumar, M. \& Swaminathan, K. Supplementation of waste tea fungal biomass as a dietary ingredient for broiler chicks. Bioresour. Technol. 96, 1743-1748 (2005).

71. Choi, M. H. \& Park, Y. H. Growth of Pichia guilliermondii A9, an osmotolerant yeast, in waste brine generated from kimchi production. Bioresour. Technol. 70, 231-236 (1999).

72. Bzducha-Wróbel, A., Kieliszek, M. \& Błazejak, S. Chemical composition of the cell wall of probiotic and brewer’s yeast in response to cultivation medium with glycerol as a carbon source. Eur. Food Res. Technol. 237, 489-499 (2013).

73. Bzducha-Wróbel, A. et al. Modification of the cell wall structure of Saccharomyces cerevisiae strains during cultivation on waste potato juice water and glycerol towards biosynthesis of functional polysaccharides. J. Biotechnol. 281, 1-10 (2018).

74. Kurihara, K. et al. Effect of CAWS, a mannoprotein-beta-glucan complex of Candida albicans, on leukocyte, endothelial cell, and platelet functions in vitro. Biol. Pharm. Bull. 26, 233-240 (2003).

75. Ha, C. H. et al. Preparation and analysis of yeast cell wall mannoproteins, immune enhancing materials, from cell wall mutant Saccharomyces cerevisiae. J. Microbiol. Biotechnol. 16, 247-255 (2006).

76. Ghareeb, K., Awad, W. A., Nitsch, S., Abdel-Raheem, S. \& Böhm, J. Effects of transportation on stress and fear responses of growing broilers supplemented with prebiotic or probiotic. Int. J. Poult. Sci. 7, 678-685 (2008).

77. Rahimi, S. \& Khaksefidi, A. A comparison between the effects of a probiotic (Bioplus 2B) and an antibiotic (Virginiamycin) on the performance of broiler chickens under heat stress conditions. Iran. J. Vet. Res. 7, 23-28 (2006).

78. Deng, W., Dong, X. F., Tong, J. M. \& Zhang, Q. The probiotic Bacillus licheniformis ameliorates heat stress-induced impairment of egg production, gut morphology, and intestinal mucosal immunity in laying hens. Poult. Sci. 91, 575-582 (2012).

79. Cengiz, Ö. et al. Effect of dietary probiotic and high stocking density on the performance, carcass yield, gut microflora, and stress indicators of broilers. Poult. Sci. 94, 2395-2403 (2015).

80. Silva, J. H. V. \& Costa, F. G. P. Tabela para codornas japonesas e europeias (ed. Funep) 107 p (Jabotical, 2009).

81. Roberts, J. R. Factors affecting egg internal quality and egg shell quality in laying hens. J. Poult. Sci. 41, 161-177 (2004).

82. Barbosa, V. M. et al. Avaliação da qualidade da casca dos ovos provenientes de matrizes pesadas com diferentes idades. Arq. Bras. Med. Vet. Zootec. 64, 1036-1044 (2012).

83. Honikel, K. O. Reference methods for the assessment of physical characteristics of meat. Meat Sci. 49, 447-457 (1998).

84. Haugh, R. R. The Haugh unit for measuring egg quality. U.S. Egg Poult. Mag. 43, 552-555 (1937).

85. Allan, W. H. \& Gough, R. E. A standard haemagglutination inhibition test for Newcastle disease. Vet. Rec. 95, 120-3 (1974).

\section{Acknowledgements}

The authors are thankful to CAPES - Brazilian Agency for Improvement of Graduate Personnel - (Brazil, grant 02338322037) and CNPq - National Council of Scientific and Technological Development - (Brazil, grant 476140/2012-9), for their financial support and for the doctorate scholarship.

\section{Author contributions}

Giana Carla Gaboardi, Diego Gil de los Santos, Fabrício Conceição, and Eduardo Xavier designed the experiment. Débora Alves, Giana Carla Gaboardi, Paula Finger, and Emili Griep performed the experiment and data collection. Eduardo Xavier and Victor Roll provided all the support for animal experimentation (collaborators, local and animals). Patricia Oliveira and Giana Carla Gaboardi produced the yeast P. pastoris X-33 for the experiment. Ana Paula Nunes contributed to the execution of histological analysis and organ collection. Victor Roll and Giana Carla Gaboardi performed the statistical analysis. Giana Gaboardi wrote the paper. Arthur Silva translated the text into English language and corrected the writing. Fabricio Conceição and Eduardo Xavier reviewed the manuscript. Ângela Moreira contributed to the raising of financial resources to the project.

\section{Competing interests}

The research was conducted without any commercial, financial, and non-financial relationship that could result in a potential conflict of interest. Therefore, all the authors declare no competing interests.

\section{Additional information}

Correspondence and requests for materials should be addressed to G.C.G.

Reprints and permissions information is available at www.nature.com/reprints. 
Publisher's note Springer Nature remains neutral with regard to jurisdictional claims in published maps and institutional affiliations.

(c) (i) Open Access This article is licensed under a Creative Commons Attribution 4.0 International License, which permits use, sharing, adaptation, distribution and reproduction in any medium or format, as long as you give appropriate credit to the original author(s) and the source, provide a link to the Creative Commons license, and indicate if changes were made. The images or other third party material in this article are included in the article's Creative Commons license, unless indicated otherwise in a credit line to the material. If material is not included in the article's Creative Commons license and your intended use is not permitted by statutory regulation or exceeds the permitted use, you will need to obtain permission directly from the copyright holder. To view a copy of this license, visit http://creativecommons.org/licenses/by/4.0/.

(c) The Author(s) 2019 